UDC 613.2

DOI: 10.21668/health.risk/2018.4.05.eng

\title{
HEALTH RISK ASSESSMENT WHEN GIVING GROUNDS FOR HYGIENIC CRITERIA OF FOOD PRODUCTS SAFETY
}

\section{P.Z. Shur, N.V. Zaitseva}

Federal Scientific Center for Medical and Preventive Health Risk Management Technologies, 82 Monastyrskaya Str., Perm, 614045, Russian Federation

Safety of any product, including food, is viewed as absence of unacceptable risks for life and health. Given that, we propose methodical approaches to health risk assessment in substantiating hygienic standards for contaminants contents in food products; these standards are to be harmonized with internationally accepted principles and supplemented with a methodology recommended by the Eurasian Economic Commission. We describe approaches to assessment of product risks with application of health risk evolution modeling; when giving grounds for hygienic standards, these approaches allow to predict health risk evolution over a period during which a consumer contacts a product; to calculate risk levels for different consumer groups, including sensitive ones; to model health risk as per preset exposure scenarios.

The article contains some examples of setting hygienic requirements to contents of chemical contaminants and biological agents in food products. Thus, a hygienic standard for contents of tetracycline antibiotics in meat products was fixed taking into account consequences of gut organisms imbalance as an increased risk of digestive organs diseases, dermatitis, food allergy, or blood diseases. When a hygienic standard for ractopamine contents in meat products was being fixed, it was shown that its occurrence in any concentration that can be detected with contemporary techniques caused unacceptable health risk in a form of functional disorders in the circulatory system. Therefore, ractopamine was to be prohibited in any concentration. When maximum permissible nitrates contents in fruit and vegetable was being substantiated, experts took into account both carcinogenic risks caused by transformation of nitrates into nitrosoamines, and health risks related to methemoglobin formation. Hygienic requirements to permissible listeria contents in food products ready for consumption were substantiated taking into account quantities of such products (primarily, dairy ones) recommended for consumption by sensitive population groups (first of all, pregnant and breast-feeding women).

The outlined experience accumulated in health risk assessment when giving grounds for hygienic criteria of food products safety in the EAEU and Russia can be useful for improvement and international harmonization of risk assessment. It is advisable to consider such basic aspects in the process as possible convergence of scientific approaches to assessing consumer health risks when substantiating hygienic standards, harmonization of risk assessment tools, exchange of experience and a constructive international discussion on practices related to substantiation of hygienic standards.

Key words: health risk assessment, hygienic standards, food products, hazard factors, level of exposure, international harmonization of risk assessment.

The Russian Federation accession to the World Trade Organization, collaboration in the Customs Union within the framework of the Eurasian Economic Community, makes sanitary legislation convergence and, in particular, harmonization of sanitary and hygienic standards of product quality in line with international standards, to be one of the highest priorities.

To date, application of the methodology for analyzing health risks while ensuring product safety is enshrined in international legal acts and national legislation of Russian Federation. Currently, the development of regulatory standards for the quality of environmental objects necessarily requires methodology for assessing risk to public health.

In the Russian Federation, first of all, they include the Federal Law "On Technical Regulation"1 No. 184-FZ, Federal Law "On Sanitary and Epidemiological Welfare of the Population" No. 52-FZ. The Russian Federation laws, as well as international documents, interpret product

(C) Shur P.Z., Zaitseva N.V., 2018

Pavel Z. Shur - Doctor of Medicine, Academic Secretary (e-mail: shur@fcrisk.ru; tel.: +7 (342) 238-33-37; ORCID: https://orcid.org/0000-0003-2356-1145).

Nina V. Zaitseva - Academician of the Russian Academy of Sciences, Doctor of Medical Sciences, Professor, Scientific Director (e-mail: znv@fcrisk.ru; tel.: +7 (342) 237-25-34; ORCID: https://orcid.org/0000-0001-5171-3105).

${ }^{1}$ On Technical Regulation (last edited on July 29, 2017): The RF federal law issued on December 27, 2002 No.184-FZ [Web-source] // KODEKS: an electronic fund of legal and reference documentation.. - URL: http://docs.cntd.ru/document/901836556 (date of visit April 22, 2017).

${ }^{2}$ On Sanitary and Epidemiologic Welfare of the Population: The RF Federal Law issued on March 30, 1999 No. 52-FL [websource] // KonsultantPlus. - URL: http://www.consultant.ru/document/cons_doc_LAW_22481/ (date of visit April 22, 2017). 
safety as the absence of unacceptable risk to consumer life and health. This is the legal basis for applying the methodology in developing hygienic standards that ensure food safety for health in Russia, and the Eurasian Economic Union.

Food products safety in Russia and the EAEU is ensured by the establishment of mandatory requirements within the framework of the Customs Union Technical Regulations. However, in the transitional period, when the complete package of technical regulations has not been finally formed, in the absence of a standard, the Unified Sanitary-Epidemiological and Hygienic Requirements for Goods subject to Sanitary and Epidemiological Surveillance (Control) shall be applied in the system of technical regulation. Hygienic standards are an integral part of technical regulations. In the field of food-stock and foodstuffs safety in Russian Federation and in the territory of the Customs Union, more than 7,000 sanitary and epidemiological indicators are monitored, 3 thousand of which were harmonized in the preparation of the regulatory system of the Customs Union Agreement on Sanitary Measures.

At the same time, it is necessary to emphasize that Russian Federation, as a member of the WTO, retained the right to establish more stringent requirements than the international ones, if needed in view of the protection level established on its territory, provided there's a competent scientific rationale developed on the basis of the risk assessment system.

It should be noted that, both in the system of technical regulation and in the Unified Sanitary and Epidemiological Requirements, hygienic standards established in the framework of the hygienic rationing concept according to "zero" risk criteria are used as indicators of food safety. These hygienic standards need to be acknowledged based on the concept of tolerable (acceptable) level of risk and, in some cases, also to be revised. Justification of hygienic standards for the quality of food products on the basis of health risk criteria is one of the key elements in harmonization with the standards adopted in global practice.

For this purpose, the basic principles for validating the risk-based standards in Russia are harmonized with international practice, primarily with the guidelines of Codex Alimentarius Com- mission [1]. They include the priority of safety, concept of non-zero risk, phasing of the procedure, preference for quantitative assessments, priority to epidemiological studies, and others.

In accordance with these principles, by now, the standards for a number of food safety hazards have already been substantiated by health risk criteria in the EAEU. First of all, they include pesticides, nitrates, tetracyclines residuals, ractopamine, and tolerable content of Listeria.

However, this is just the beginning of a big job. To systematically implement it, food priority items, such as bakery, confectionery, vegetable oil, milk, meat products, etc., were identified using the production and consumption criteria. Priority pollutants of food products were identified. These include metals, mycotoxins, antibiotics and a number of organic compounds. As one of the identification criteria, we consider the absence of a harmonized approach to justification of the existing standards.

Methodical approaches to risk assessment for the tasks of validating the hygienic standards are basically identical to the general practice of food safety health risk assessment.

In line with the phasing approach to health risk assessment procedure, the development of quality standards using risk criteria includes phases of hazard identification, exposureresponse assessment, exposure assessment and risk profile. However, to solve the problems of validating the hygienic standards, these phases are defined by a number of features.

So, when defining a hazard, no hazard factors are being identified, since a certain factor is already under regulation. The major focus is made to the in-depth analysis of the information available on its features, sources and actual content levels in products, to studying hygienic norms and standards in global practice. The framework to form probable effects of exposure and identification of the most sensitive contingents, including the individual sensitivity markers being applied, is also subject to evaluation.

Based on hazard identification, a decision is made about the need for and the possibility for further procedure to justify risk-based standards.

The peculiarities of exposure-response assessment phase for chemical factors, and characteristics of hazard for microbiological factors, is the establishment of no observed effect levels 
and/or threshold exposure levels in laboratory and epidemiological studies. As the no observed effect levels, the values characterizing the absence of an adverse effect (NOAEL) are most often considered. When validating hygienic standards according to the findings of epidemiological studies, reference levels of exposure (BMD, BMC) are often used.

An important component in the "exposureeffect (response)" assessment phase is the analysis and, if necessary, mathematical models that describe quantitatively the dependences of the adverse effect probability on the level of exposure. At this stage, the parameters of health risk evolution models, recommended by the Eurasian Economic Commission as a tool for risk assessment of products, including food, can be justified.

When validating hygienic standards in the exposure assessment phase, the scenarios are formed, which foresee the maximum possible, standard, and actual level of exposure. In scenarios that provide standard and actual level of exposure, it is advisable to consider the exposure profile for the most sensitive population groups. The exposure assessment for the tasks of validating hygienic standards by health risk criteria is done indirectly and directly, and the methods addressed to examining the exposure markers are very much in demand.

The risk profile is developed step-by-step for the scenarios considered at the stage of exposure assessment using the parameters and models chosen in the "exposure-effect (response)" assessment. In the event, if the maximum possible exposure level does not lead to unacceptable health risk, the remaining scenarios need not be considered. Through risk profiling phase, we establish the levels of risk factors in environmental objects or products that provide the maximum exposure that determines tolerable (acceptable) level of health risk. These values are considered risk-based standards.

In the course of profiling risk, for the tasks of justifying hygienic standards, there are some relevant aspects of this process as follows:

- Assessment of the threshold (reference) levels uncertainty and identification of the modifying factors;

- Assessment of the adverse effects severity;

- Identifying levels of tolerable (acceptable) level of health risk.
To ensure that a hygienic standard reliably provides the level of risk not higher than the tolerable, based on the uncertainty analysis of risk assessment, there are safety factors/modifying factors established, upon which the threshold or no observed effect levels are reviewed. For example, when using findings of the epidemiological study made for the most sensitive recipients groups, the modifying factors can be equal to 1 .

An important issue in establishing riskbased standards is the identification of the tolerable (acceptable) level of risk. Today, in Russia it is customary to consider the value of $1 \cdot 10^{-4}$ as an acceptable level of health risk. This level characterizes lifelong risk of death or disease with a severity close to unity.

Assessing the severity of various effects (responses) has an essential role in the quantitative assessment of risk, and may affect the value of hygienic standards validated by risk criteria. The value characterizing the severity effect of 0 - absolute health, up to 1 - death is determined also on the basis of the expert assessments, including the standardized scales for disease severity applied. For example, when calculating DALY index used by the World Health Organization (WHO) to estimate harm due to diseases, a severity index standardized relative to the state of death is used.

A quantitative assessment of health risk, taking into account the severity of the probable responses, showed that consumption of food products containing residual tetracyclines at a level of $10 \mu \mathrm{g} / \mathrm{kg}$ and higher could lead to unacceptable risk to the health of children population. The standards for the tolerable levels of tetracycline - the acceptable daily intakes (ADI), and the maximum residues level in food (MRL) were recorded in 1990 in the thirty-sixth report of the Joint FAO/WHO Expert Committee on Food Additives (JECFA) [2].

The no-observed effect level (NOEL) of tetracycline is set at $2 \mathrm{mg}$ per day. The study results of tetracycline effects on humans served as the basis here. As a critical effect, we considered the impact on intestinal microflora (increased coliform resistance). With the establishment of an acceptable daily intake ( $3 \mu \mathrm{g}$ per kg of body weight, per day), the uncertainty factor of 10 was taken, due to variability of intestinal flora in humans. 


$$
A D I=\frac{M_{50}(\mu g / g) \times \text { IntestinesContentMass }(220 \mathrm{~g})}{\text { Bio-availablePeroralDose } \times \text { StockFactor } \times \text { IndividualBodyMass }(60 \mathrm{~kg})}
$$

In the fortieth report of the Joint FAO/WHO Expert Committee on Food Additives, the acceptable daily intake of tetracyclines was reconsidered [3]. On the basis of the Committee's conclusion that the variability is small among individuals and the uncertainty factor is no longer appropriate, it is therefore advisable to take $30 \mu \mathrm{g}$ per $\mathrm{kg}$ of body weight per day as an acceptable daily dose. To quantify the risk, we calculated tolerable daily doses for tetracycline and oxytetracycline for different types of microorganisms by the formula (1) recommended by FAO/WHO [4].

The formula was developed based on $\mathrm{MIC}_{50}$ modal value $\left(\mathrm{MIC}_{50}\right.$ is the minimum antibiotic concentration that inhibits growth of $50 \%$ of cultures of a particular microorganism), the safety factor to consider different types of variability, the intestinal contents, the weight of an individual, and the bioavailability of the antibiotic oral dose. $\mathrm{MIC}_{50}$ values of tetracycline and oxytetracycline for 10 different microorganisms were taken in accordance with the WHO Food Additives Series 36, with safety factor value of 1 , the proportion of tetracyclines bioavailable oral dose of 0.6 , the mass of intestinal contents of $220 \mathrm{~g}$, the average mass of an individual $-60 \mathrm{~kg}$.

The acceptable daily intakes for 10 different types of microorganisms obtained in the calculation, by the formula (1), varied from $0.37 \mu \mathrm{g} / \mathrm{kg}$ body weight relative to Clostridium spp. up to $195.6 \mu \mathrm{g} / \mathrm{kg}$ body weight for Escherichia coli and Proteus spp. (Table 1); such a high variability in the results may indicate the need to include an additional uncertainty factor in the calculation of a tolerable daily dose, especially for the most sensitive population groups, for example children, to carry out health risk assessment, taking into account the parameters of these groups.

Table 1

Examples of acceptable daily intakes of variable microorganisms

\begin{tabular}{|l|c|}
\hline \multicolumn{1}{|c|}{ Microorganism } & $\begin{array}{c}\text { Acceptable Daily } \\
\text { Intake, } \mu \mathrm{g} / \mathrm{kg}\end{array}$ \\
\hline Escherichia coli & 195.56 \\
\hline Bifidobacterium spp. & 97.78 \\
\hline Bacteroides fragilis & 24.44 \\
\hline Eubacterium spp. & 12.22 \\
\hline Clostridium spp. & 0.38 \\
\hline Streptococcus spp. & 97.78 \\
\hline Fusobacterium spp. & 0.76 \\
\hline Lactobacillus spp. & 12.22 \\
\hline Proteus spp. & 195.56 \\
\hline Peptostreptococcus spp. & 12.22 \\
\hline
\end{tabular}

The formation of an imbalance in intestinal microbial flora, according to in vitro studies, can be illustrated by the results of mathematical modeling of facultative microflora growth against the background of obligate flora suppression $^{3}$, primarily of Bifidobacterium.

Scientific studies devoted to pathogenetic processes in the intestine ${ }^{4}[2-8]$ present materials on the occurrence of microorganisms imbalance of varying degree for various diseases (Table 2, 3) [5].

According to the studies' results in the whole population, these diseases are associated with a change in the microflora of the first class: from 18.6 to $34.8 \%$, the second: from 24.2 to $45.7 \%$, the third: from 27.0 to $56.3 \%$. In the children's population, there is also an imbalance of the intestinal microflora in these diseases: of the first class: from 2.0 to $74.0 \%$, the second class: from 26.0 to $84.0 \%$ and the third: from 0.0 to $39.1 \%$.

\footnotetext{
${ }^{3}$ Petrenko V.V. Clinical and pathogenetic peculiarities and ways to treat dysbacteriosis in the intestines and dislipidemia in patients with functional constipation: thesis of the dissertation for candidate of medical sciences degree. - Saint Petersburg, 2009. - 122 p. Gusakova E.V. Interference currents applied in complex sanatorium-resort treatment of patients with irritable bowels syndrome: thesis of the dissertation for candidate of medical sciences degree. - Moscow, 2003. - $121 \mathrm{p}$.

Orlova N.A. Dysbiosis and possible ways to treat it in patients with inflammatory intestines diseases with combined pathologies and/or symptoms beyond the intestines: thesis of the dissertation for candidate of medical sciences degree. - Saint Petersburg, 2010. - $130 \mathrm{p}$.

${ }^{4}$ Ivanova T.N. Microbiological peculiarities of dysbiosis in people living in the polar regions: thesis of the dissertation for candidate of medical sciences degree. - Saint Petersburg, 2008. - 159 p.
} 
Table 2

Occurrence of intestinal microflora microorganisms imbalance in various diseases (adults), $\%$

\begin{tabular}{|l|c|c|c|c|}
\hline \multicolumn{1}{|c|}{ Group (code ICD10) } & Absence & $\begin{array}{c}1 \text { class } \\
\text { severity }\end{array}$ & $\begin{array}{c}2 \text { class } \\
\text { severity }\end{array}$ & $\begin{array}{c}3 \text { class } \\
\text { severity }\end{array}$ \\
\hline IBS with diarrhea (K58.0) & 0 & 37.8 & 35.1 & 27.0 \\
\hline IBS without diarrhea (K58.9) & 0 & 18.6 & 45.8 & 35.6 \\
\hline Constipation (K59.0) & 0 & 21.2 & 24.2 & 54.5 \\
\hline Inflammatory bowel disorder (K50-K51) & 0 & 0.00 & 43.7 & 56.3 \\
\hline
\end{tabular}

Table 3

Occurrence of intestinal microflora microorganisms imbalance in various diseases (children)

\begin{tabular}{|l|c|c|c|c|}
\hline \multirow{2}{*}{ Group (code ICD10) } & \multicolumn{4}{c|}{ Imbalance, \% } \\
\cline { 2 - 5 } & $\begin{array}{c}\text { No } \\
\text { disorders }\end{array}$ & $\begin{array}{c}\text { 1class } \\
\text { severity }\end{array}$ & $\begin{array}{c}2 \text { class } \\
\text { severity }\end{array}$ & $\begin{array}{c}3 \text { class } \\
\text { severity }\end{array}$ \\
\hline IBS with diarrhea (K58.0) & 0 & 22.2 & 66.7 & 11.1 \\
\hline Constipation (K59.0) & 0 & 74.0 & 26.0 & 0 \\
\hline Functional bowel disorder, unspecified (K59.9) & 0 & 15.0 & 84.0 & 1.0 \\
\hline Iron deficiency anemia (D50) & 0 & 39.8 & 46.6 & 13.6 \\
\hline Other atopic dermatitis (L20.8) & 0 & 40.6 & 37.2 & 22.2 \\
\hline Duodenitis (K29.8, K29.9) & 26.7 & 31.5 & 33.7 & 8.1 \\
\hline Food allergies (T78.0, T78.1, T78.4) & 1.4 & 12.6 & 46.9 & 39.1 \\
\hline General variable immunodeficiency, unspecified (D83.9) & 0 & 2.0 & 80.0 & 18.0 \\
\hline
\end{tabular}

Based on the average daily intakes of animal origin food products in Europe and daily intakes of animal origin food for the adult population in Russian Federation, as well as the values of tetracycline maximum residual levels (MRL) recommended by the WHO (1990), FAO/WHO (1998) adopted in the USA, and the maximum tolerable levels in the Customs Union, the maximum daily intake of tetracycline with food was established for 10 exposure scenarios.

Modeling the imbalance in the intestine microflora upon calculation of the values for the maximum daily intake and tetracycline concentration in the gastrointestinal tract for the exposure scenarios studied made it possible to establish that the scenarios harmlessness to health (the content of facultative microorganisms does not exceed $5 \%$ of the total number of bacteria) were the ones, which assumed the intake of tetracyclines residual amounts not exceeding $10 \mu \mathrm{g} / \mathrm{kg}$ per day.

The risk contingent, people with tetracycline-sensitive intestinal microflora, account for up to $70 \%$ of the population [6]. With this in mind, the consumption of food products containing tetracyclines may increase the risk of a number digestive system disorders
(K58.0, K58.9, K59.0, K50-K51) in the population of Russia by $23 \%$ of cases, if the balance of the intestinal microflora is disturbed. As the reference most sensitive population for the quantitative health risk assessment, children aged 1-11 years were considered. Assessing the risk of developing an intestinal microflora imbalance and further increase in the risk of associated diseases in children, considering the exposure peculiarities for this group, showed that the risk of developing an intestinal microflora imbalance under tetracyclines effect for this group was absent only when consuming food with residual amounts of antibiotics in food products at a level not higher than $10 \mu \mathrm{g} / \mathrm{kg}$.

If there is an imbalance of intestinal microflora in children, including those caused by residual tetracycline concentrations in food products of more than $10 \mu \mathrm{g} / \mathrm{kg}$, the risk of digestive system disorders increases to 0.000461 , of dermatitis - to 0.000725 , food allergy - to 0.000149 , of blood diseases - up to 0.001372 . An increase in the risk of digestive system sick rate in children's population in Russian Federation can be up to $4 \%$ of cases, blood diseases up to $8 \%$ of cases, skin diseases - up to $0.9 \%$ of cases, allergies - up to $0.1 \%$ of cases. 
With the quantitative assessment of microbiological risk applied, taking into account its severity showed that the standards for Listerium content in a number of the EAEU food products ensure safety of consumers' health in contrast to the norms recommended by the Codex Alimentarius Commission for products in trade.

Listeriosis, caused by L. Monocytogenes intake with food, is relatively rare, but a serious disease affecting mainly sensitive population groups. The infection source and route is usually unknown, but the food contaminated with L. Monocytogenes is considered the main path of infection and the cause of $99 \%$ of Listeriosis cases [7].

According to the Centers for Disease Control and Prevention, in 2000, L. Monocytogenes ranked second in terms of mortality (21\%) among all the foodborne infections pathogens under monitoring by the organization, and the number one in the rate of hospitalization $(90.5 \%)$. The mortality in cases of invasive listeriosis among the hospitalized patients was $20-30 \%[8,9]$.

The most frequent sources of Listeriosis outbreaks are various kinds of soft cheeses, processed meat, salami, pasteurized milk, unpasteurized milk, raw vegetables, etc. [10].

In accordance with the requirements of the Customs Union Technical Regulations and the Unified Sanitary Requirements, L. Monocytogenes content in $25 \mathrm{~g}$ of product is not allowed, which corresponds to a tolerable level of bacteria content of L. Monocytogenes $/ \mathrm{g}$ $0.04 \mathrm{CFU}$ for all product groups under study.

The primary document of Codex Alimentarius that contains requirements for tolerable levels of L. Monocytogenes in food is CAC/GL61-2007 [11]. In accordance with CAC/GL61-2007, the criterion value for the allowable content of L. Monocytogenes in food products is chosen based on the probability of growth and reproduction of bacteria in the product group under study. Thus, for food products that do not support growth and reproduction of L.Monocytogenes due to their physicochemical properties, an acceptable level of bacteria in $100 \mathrm{CFU}$ of L. Monocytogenes/g is established, and for food products in which growth and reproduction of L. Monocytogenes is possible $-0.04 \mathrm{CFU}$ of L. Monocytogenes/g. The content of L.Monocytogenes in fish, fruit and vegetable products is standardized by CAC/GL 21-1997 [12] in accordance with the established requirements for the production, and using the HACCP system.

In the European Union countries, in accordance with EU Regulation 1441/2007 [17], the criteria for L.Monocytogenes content for infant formula and therapeutic food products (0.04 CFU L. Monocytogenes/g) are established, for other foods, in which L. Monocytogenes growth and reproduction are possible (100 CFU L.Monocytogenes/g in market circulation, $0.04 \mathrm{CFU}$ L.Monocytogenes/g before being released to the market by the manufacturer), as well as for other products that do not support L.Monocytogenes growth and reproduction (100 CFU L.Monocytogenes/g).

To assess population health risks associated with the intake of L.Monocytogenes with food products, dose-response models were used. In this context, the dose is understood as the amount of microorganisms coming through gastrointestinal tract. An adverse health effect was considered as the probability of infection, development of a disease or onset of death. Such models, as a rule, are constructed using the known statistical functions of probability distribution, the dependencies ratios are determined from the findings of epidemiological studies. It should be noted that in the models considered, dose-response dependencies are described at the population level, the disease probability at the level of an individual is not estimated. In assessing risk, attention should be paid to the characteristics of the population being studied, in particular, to the immune status.

One of the simplest and most frequently used models is an exponential model with one parameter $[14,15]$ :

$$
P_{i}=1-\exp \left[-r_{i} \cdot N_{i}\right],
$$

where $P_{i}$ is a disease probability after intake of $i$-th product, $N_{i}$ is a consumed dose of microorganisms, $r_{i}$ - parameter corresponding to a disease probability when exposed to a single microorganism.

Equation (2) is widely used to assess the likelihood of diseases caused by the action of 
Listeria Monocytogenes [16]. In calculating the risk of disease in people with normal immunity, the known coefficients were used for three types of products:

1. Smoked fish: $r_{1}=5.6 \cdot 10^{-10}[22]$;

2. Chocolate milk: $r_{2}=5.8 \cdot 10^{-12}[21]$.

3. Tuna-corn salad (vegetables): $r_{3}=1.8 \cdot 10^{-8}[16]$.

The daily dose of microorganisms was calculated at the exposure assessment phase.

When assessing risk of a disease after consuming several types of products, we used the probability summation hypothesis: $P=\sum_{i} P_{i}$, which is valid for small values of $P_{i}$.

To calculate the probability of a disease in people of the sensitive group, a coefficient $r=3.15 \cdot 10^{-7}$ was used.
The exposure assessment was based on the average daily intake of food groups considered to be the most probable sources of L. Monocytogenes [18] by different population groups and the tolerable content of L. Monocytogenes in food. For the Russian Federation population, several options were considered for daily intakes by the adult population, including pregnant and lactating women of the following food categories: vegetables, fruits, fat products, dairy products, meat products, fish (seafood) used to assess the exposure to L. Monocytogenes [17]. Pregnant and lactating women were considered as the population sensitive groups. The exposure scenarios characteristics are presented in Table 4.

The maximum daily intake of L. Monocytogenes with food products, taking into account the optimal average daily intake of food for pregnant and lactating women, is shown in Table 5.

Table 4

Characteristics of exposure scenarios

\begin{tabular}{|c|l|c|}
\hline Scenario & \multicolumn{1}{|c|}{ Set of Food Products } & $\begin{array}{c}\text { Tolerable content } \\
\text { of L. Monocytogenes } \\
\text { in a food product, } \\
\text { CFU/g }\end{array}$ \\
\hline 1 & Recommended daily intake of food products in Russian Federation & $0.04^{* *}$ \\
\hline 2 & Recommended daily intake of food products in Russian Federation & 100 \\
\hline 3 & $\begin{array}{l}\text { Actual daily intake of food products by the adult population in Rus- } \\
\text { sian Federation }\end{array}$ & 0.04 \\
\hline 4 & $\begin{array}{l}\text { Actual daily intake of food products by the adult population in Rus- } \\
\text { sian Federation }\end{array}$ & 100 \\
\hline 5 & $\begin{array}{l}\text { Optimal average daily food intake for pregnant women, completed by } \\
\text { modeling results for Scenario 1 (vegetables and fish)* }\end{array}$ & 0.04 \\
\hline 6 & $\begin{array}{l}\text { Optimal average daily food intake for pregnant women, completed by } \\
\text { modeling results for Scenario 2 (vegetables and fish)* }\end{array}$ & 100 \\
\hline 7 & $\begin{array}{l}\text { Optimal average daily food intake for pregnant women, completed by } \\
\text { modeling results for Scenario 3 (vegetables and fish)* }\end{array}$ & 0.04 \\
\hline 8 & $\begin{array}{l}\text { Optimal average daily food intake for pregnant women, completed by } \\
\text { modeling results for Scenario 4 (vegetables and fish)* }\end{array}$ & 100 \\
\hline 9 & $\begin{array}{l}\text { Optimal average daily food intake for lactating women, completed by } \\
\text { modeling results for Scenario 1 (vegetables and fish)* }\end{array}$ & 0.04 \\
\hline 10 & $\begin{array}{l}\text { Optimal average daily food intake for lactating women, completed by } \\
\text { modeling results for Scenario 2 (vegetables and fish)* }\end{array}$ & 100 \\
\hline 11 & $\begin{array}{l}\text { Optimal average daily food intake for lactating women, completed by } \\
\text { modeling results for Scenario 3 (vegetables and fish)* }\end{array}$ & 0.04 \\
\hline 12 & $\begin{array}{l}\text { Optimal average daily food intake for lactating women, completed by } \\
\text { modeling results for Scenario 4 (vegetables and fish)* }\end{array}$ \\
\hline
\end{tabular}


Table 5

The maximum daily intake of L.Monocytogenes with food products, taking into account the optimal average daily intake of food for pregnant and lactating women (g, gross), fully providing for their physiological needs for food substances and energy

\begin{tabular}{|c|c|c|c|c|}
\hline \multirow[b]{2}{*}{$\begin{array}{l}\text { Food products } \\
\text { group } \\
\text { Food products } \\
\text { group }\end{array}$} & \multicolumn{2}{|c|}{$\begin{array}{l}\text { L. Monocytogenes CFU } \\
\text { (tolerable content of L.Monocytogenes } \\
\text { in food product } 0.04 \mathrm{CFU} / \mathrm{g} \text { ) }\end{array}$} & \multicolumn{2}{|c|}{$\begin{array}{l}\text { L. Monocytogenes CFU } \\
\text { (tolerable content of L.Monocytogenes } \\
\text { in food product } 100100 \mathrm{CFU} / \mathrm{g} \text { ) }\end{array}$} \\
\hline & $\begin{array}{l}\text { L. Monocytogenes } \\
\text { CFU (tolerable } \\
\text { content of } \\
\text { L.Monocytogenes } \\
\text { in food product } \\
0.04 \text { CFU } / g \text { ) }\end{array}$ & $\begin{array}{l}\text { L. Monocytogenes } \\
\text { CFU (tolerable } \\
\text { content of } \\
\text { L.Monocytogenes } \\
\text { in food product } \\
100100 \mathrm{CFU} / \mathrm{g} \text { ) }\end{array}$ & $\begin{array}{l}\text { L. Monocytogenes } \\
\text { CFU (tolerable } \\
\text { content of } \\
\text { L.Monocytogenes } \\
\text { in food product } \\
0.04 \mathrm{CFU} / \mathrm{g} \text { ) }\end{array}$ & $\begin{array}{l}\text { L. Monocytogenes } \\
\text { CFU (tolerable } \\
\text { content of } \\
\text { L.Monocytogenes } \\
\text { in food product } \\
100 \mathrm{CFU} / \mathrm{g} \text { ) }\end{array}$ \\
\hline Vegetables & 20 & 5000 & 20 & 5000 \\
\hline Fruits & 12.8 & 3200 & 12.8 & 3200 \\
\hline Fat products & 2.48 & 6200 & 2.48 & 6200 \\
\hline Dairy & 23.6 & 5900 & 27.6 & 6900 \\
\hline Meat products & 6.8 & 1700 & 6.8 & 1700 \\
\hline Fish (seafood) & 2.8 & 700 & 2.8 & 700 \\
\hline
\end{tabular}

Table 6

Results of assessing Listeriosis probability

\begin{tabular}{|l|c|c|c|c|c|c|}
\hline Food products group & Scenario 1 & Scenario 2 & Scenario 3 & Scenario 4 & Scenario 5 & Scenario 6 \\
\hline Vegetables & $2.76 \mathrm{E}-07$ & $\mathbf{6 . 8 9 E}-04$ & $1.41 \mathrm{E}-07$ & $\mathbf{3 . 5 3 E - 0 4}$ & $2.76 \mathrm{E}-07$ & $\mathbf{6 . 8 9 E}-04$ \\
\hline Dairy & $2.16 \mathrm{E}-10$ & $5.40 \mathrm{E}-07$ & $1.29 \mathrm{E}-10$ & $3.22 \mathrm{E}-07$ & $7.43 \mathrm{E}-06$ & $\mathbf{1 . 8 6 E - 0 3}$ \\
\hline Meat products & - & - & - & - & - & - \\
\hline Fish & $1.35 \mathrm{E}-09$ & $3.37 \mathrm{E}-06$ & $5.38 \mathrm{E}-10$ & $1.34 \mathrm{E}-06$ & $1.35 \mathrm{E}-09$ & $3.37 \mathrm{E}-06$ \\
\hline Total & $2.77 \mathrm{E}-07$ & $\mathbf{6 . 9 3 E - 0 4}$ & $1.42 \mathrm{E}-07$ & $\mathbf{3 . 5 4 E - 0 4}$ & $7.71 \mathrm{E}-06$ & $\mathbf{2 . 5 5 E - 0 3}$ \\
\hline Food products group & Scenario 1 & Scenario 2 & Scenario 3 & Scenario 4 & Scenario 5 & Scenario 6 \\
\hline Vegetables & $1.41 \mathrm{E}-07$ & $\mathbf{3 . 5 3 E - 0 4}$ & $2.76 \mathrm{E}-07$ & $\mathbf{6 . 8 9 E - 0 4}$ & $1.41 \mathrm{E}-07$ & $\mathbf{3 . 5 3 E - 0 4}$ \\
\hline Dairy & $7.43 \mathrm{E}-06$ & $\mathbf{1 . 8 6 E - 0 3}$ & $8.69 \mathrm{E}-06$ & $\mathbf{2 . 1 7 E - 0 3}$ & $8.69 \mathrm{E}-06$ & $\mathbf{2 . 1 7 E - 0 3}$ \\
\hline Meat products & - & - & - & - & - & - \\
\hline Fish & - & - & - & - & - & $1.34 \mathrm{E}-06$ \\
\hline Total & $5.38 \mathrm{E}-10$ & $1.34 \mathrm{E}-06$ & $1.35 \mathrm{E}-09$ & $3.37 \mathrm{E}-06$ & $5.38 \mathrm{E}-10$ & $\mathbf{2 . 5 2 E - 0 3}$ \\
\hline
\end{tabular}

Based on the results of the dose-response modeling, the integrated probability of Listeriosis development was obtained for 12 exposure scenarios (Table 6).

Thus, for all exposure scenarios developed taking into account the maximum allowable content of L.Monocytogenes in a readyto-eat and marketed food product (L. Monocytogenes/g $100 \mathrm{CFU}$ ), the risk of Listeriosis is assessed as unacceptable to population.

In exposure scenarios using the allowable content of L. Monocytogenes at the end-point of food production (L.Monocytogenes/g 0.04 CFU), the risk level of health disorders associated with the intake of L.Monocytogenes with food is characterized as negligible (scenarios based on the optimal and actual daily consumption of food products by the Russian Federation population) and allowable (scenarios based on the optimal average daily set of food products for pregnant and lactating women).

In some cases, when validating hygiene standards, along with a quantitative assessment of the health risk, a quantitative estimate of the probable effect is used.

So, to solve the important task of validating the permissible levels of nitrate content in crop products used in the countries of the Customs Union, carcinogenic risk assessment was applied, taking into account the probable relationship between nitrate levels and the concentration of nitrosamines that are carcinogens in 
food products, as well as the probability of developing non-carcinogenic effects [19].

The most sensitive population group is children. This is due to a number of factors: a higher level of fluid intake per $\mathrm{kg}$ of body weight, an increased risk of developing intestinal infections, an increased hemoglobin susceptibility to oxidation compared with adults, an incompleteness of the gastrointestinal tract leading to an elevated $\mathrm{pH}$ in stomach, which in turn creates favorable environment for nitrate-reducing microflora and reduction of nitrates to nitrites; in addition, the presence of a less active methaemoglobinreductase in children of early age, in comparison with older children and adults, and hence its ability to metabolize excess methaemoglobin.

At the stage of assessing the dose-response relationship based on the published findings of the studies dedicated to nitrates action, we constructed exponential models for the dependence of non-carcinogenic (3) (methemoglobinemia) [20] and carcinogenic (4) [21] responses on the nitrates intake with food products of plant origin. When modeling the probability of methemoglobinemia occurrence, we took into account the conversion of $8 \%$ of nitrates, supplied with food products into nitrites.

$$
\begin{aligned}
& y=1-e^{0,000639 \cdot \mathrm{x}} \\
& y=1-e^{1,44 \mathrm{E}-07 \cdot \mathrm{x}}
\end{aligned}
$$

Where: $y$ is the percentage of methhemoglobin in blood (3), carcinogenic risk (4), and $x$ is the amount of nitrate ingested (mg/person/day).
The exposure was assessed on the basis of the recommended and actual average daily consumption of plant foods in Russian Federation and the acceptable levels of nitrates in them in the Customs Union countries. During exposition assessment, 5 scenarios were developed, taking into account the receipt of nitrates with vegetable origin food at the recommended intake level for vegetables and potatoes (maximum values within the range) (scenario 1), with an average actual level of consumption by the population aged 1 to 11 years (scenario 2), aged 11 to 18 (scenario 3), aged 18 to 60 (scenario 4), over the age of 60 (scenario 5), and the acceptable levels of nitrate content in vegetables and potatoes adopted in the countries of the Customs Union.

For the developed scenarios, the possible daily intake of nitrates with vegetables and potatoes, as well as doses of nitrates using standard mean body weight for children $(22.6 \mathrm{~kg})$, adolescents $(53 \mathrm{~kg})$ and adults $(60 \mathrm{~kg})$ was calculated. The obtained levels of possible daily intake of nitrates and the values of daily doses for nitrates supplied with products of plant origin for different scenarios are presented in Table 7.

Based on modeling the dose-response relationship, the probable levels of methaemoglobin were obtained for 5 levels of exposure being considered (Table 8 ).

Methaemoglobin levels for all the scenarios studied range from $0.24 \%$ (scenario 2 ) to $1.03 \%$ (scenario 1). Considering that the background level of methaemoglobin is from 1 to $3 \%$, and the health disorders are observed at the levels of higher than $10 \%$, the results of

Table 7

Levels of nitrates intake with crop products and the corresponding dose for different exposure scenarios

\begin{tabular}{|l|c|c|c|c|c|}
\hline & Scenario 1 & Scenario 2 & Scenario 3 & Scenario 4 & Scenario 5 \\
\hline Nitrate intake, $\mathrm{mg} /$ day & 202.2 & 47.9 & 70.5 & 87.5 & 84.0 \\
\hline Nitrates dose, $\mathrm{mg} / \mathrm{kg} /$ day & 3.4 & 2.1 & 1.3 & 1.5 & 1.4 \\
\hline
\end{tabular}

Table 8

Probable levels of methaemoglobin for various exposure conditions with nitrates

\begin{tabular}{|c|c|c|}
\hline Scenario & Nitrates intake with food of vegetable origin, $\mathrm{mg} /$ day & Methemoglobin level, \% \\
\hline Scenario 1 & 202.2 & 1.03 \\
\hline Scenario 2 & 47.9 & 0.24 \\
\hline Scenario 3 & 70.5 & 0.36 \\
\hline Scenario 4 & 87.5 & 0.45 \\
\hline Scenario 5 & 84.0 & 0.43 \\
\hline
\end{tabular}


health risk assessment for permissible nitrate levels in crop products showed that the predicted non-carcinogenic effect - methemoglobinemia ranged within the limits of the background level. This allows the conclusion that there is no unacceptable risk of developing non-carcinogenic effects (methemoglobinemia) associated with the intake of nitrates with plant origin foodstuffs.

The level of carcinogenic risk for all the investigated exposure scenarios is at the level of the maximum permissible $\left(1 \times 10^{-6}-1 \times 10^{-4}\right)$, with the maximum carcinogenic risk obtained for scenario 1, taking into account the recommended standards for the consumption of plant foods and tolerable values for the content of nitrates in these products $\left(2.92 \times 10^{-5}\right)$.

Within the framework of cooperation between the scientific institutions of Russia, Belarus and Kazakhstan the new approaches to risk assessment of products using modeling of health risk evolution were proposed [22].

When validating hygiene standards, the below approaches allow:

- to predict evolution of the health risk during the period of consumer contact with products;

- to calculate risk level for different groups of consumers, including the sensitive;

- to model health risks according to the specified exposure scenarios

The evolutionary model of health risk accumulation (evolution of disorders risk in organs and body systems functions), when using products (goods), is a mathematical description of the consumers health status changes under the exposure to harmful factors' complex typical of products (goods) with a long time. Evolution of disorders risk in organs and body systems functions is caused by mechanisms of two types: natural abnormalities associated with cells damage in organs, and risk increment due to non-standardized effect of factors common for products (goods).

The evolutionary model for accumulation of risk to consumer health from products (goods) is constructed on the basis of paired dependences that reflect influence of factors inherent in products (goods) on the state of human health and shown forth in scientific publications. Pair dependencies are included in the evolutionary model of accumulating risk to consumers' health of products (goods) using the algorithms for their adaptation to computational forms.

The computational form for evolutionary model is the system of recurrence relations recorded for each type of response (health disorder). The general form of the recurrence relations is given by the expression (5) [23-25]:

$$
R_{t+1}^{i}=R_{t}^{i}+\left(\alpha_{i} R_{t}^{i}+\sum_{j} \Delta R_{t}^{i j}\right) C,
$$

Where:

$R_{t+1}^{i}$ is a risk of health disorders by the $i$ th respond at a time $t+1$;

$R_{t}^{i}$ is a risk of health disorders by the $i-t h$ respond at a time $t$;

$\alpha_{i}$ is a coefficient that takes into account the evolution of risk due to natural causes;

$\Delta R_{t}^{i j}$ is increment of health disorders risk by the $i$-th response, due to the $j$-th factor for 1 year from the time $t$;

$C$ is a time empirical coefficient.

Empirical coefficient of time allows for execution of calculations with a time step of less than 1 year. The coefficient' values per different time steps are shown in Table 9.

Table 9

The value of time empirical coefficient (C), depending on the time step

\begin{tabular}{|c|c|c|c|c|c|}
\hline $\begin{array}{c}\text { Time } \\
\text { step, } t\end{array}$ & 1 hour & 1 day & 1 week & 1 moth & 1 year \\
\hline$C$ & 0.000114 & 0.00274 & 0.019231 & 0.083333 & 1 \\
\hline
\end{tabular}

In evolutionary modeling, we consider:

- risk of non-infectious non-carcinogenic impairment of body organs and systems functions under exposure to chemical agents (noncarcinogenic substances);

- risk of carcinogenic effects (malignant neoplasms) caused by exposure to chemical agents (carcinogens);

- risk of infectious and parasitic diseases when exposed to biological agents.

Increment of health disorders risk due to the factors typical of products (goods) is determined on the basis of paired dependences (6):

$$
\Delta R_{t}^{i j}=\beta_{i j} f^{i j}\left(X_{t}^{j}\right),
$$


Where:

$\Delta R_{t}^{i j}$ is increment of health disorders risk by the $i$-th response, due to the $j$-factor during 1 year from the time $t$;

$\beta_{i j}$ is a coefficient that reflects the influence of the $j$-th factor common for products (goods) on the rate of accumulating the risk of the $i$-th effect (response);

$f^{i j}\left(X_{t}^{j}\right)$ is a function that reflects the relationship between the $j$-th factor exposure and the risk of health disorders by the $i$-th effect (response);

$X_{t}^{j}$ is exposure of the $j$-th factor at a time $t$.

The particular form of $f^{i j}\left(X_{t}^{j}\right)$ function and the values of $\beta_{i j}$ coefficients may be different for each pair "factor - effect (response)" in view of different mechanisms of the factors and methods for constructing models.

Coefficients that take into account risk evolution due to natural causes $\left(\alpha_{i}\right)$ are determined based on the background morbidity and mortality rates for the diseases classes (in the case of non-carcinogenic risk) and the specific ICDs (in the assessment of carcinogenic effects risk), reflecting the functional impairment of critical organs and systems.

When choosing the no observed exposure levels for chemical risk factors of products (goods), there are some peculiarities as follows:

- in establishing the no observed level, focus to the critical effects (critical organs/system), which arise at the lowest exposure level (for non-carcinogenic action);

- establishing the no observed level for different time characteristics of the exposure (acute, chronic);

- absence of the no observed level for carcinogenic effects of chemicals with a genotoxic mechanism.

The characteristics (parameters) of the dose-response relationship are:

- version of the dependence that reflects an increase in the probability of developing a dangerous reaction with increasing the dose (concentration) by $1 \mathrm{mg} / \mathrm{kg}$, or $1 \mathrm{mg} / \mathrm{m}^{3}\left(\mathrm{SF}_{\mathrm{i}}\right.$, $\mathrm{SF}_{\mathrm{o}}, \mathrm{SF}_{\mathrm{d}}, \mathrm{UR}$ );

- level of exposure associated with a certain probability of the effect;
- safe level of exposure (for non-carcinogens and carcinogens with a non-genotoxic mechanism).

When assessing microbiological risk, the "exposure-response" assessment is included into hazard characterization phase. The features of the "exposure-response" dependencies assessment for biological factors include:

- analysis of susceptibility of a risk contingent to the effects of biological hazards of products (goods);

- need to evaluate (using laboratory data) the sources and methods for preparing stuff containing pathogens;

- taking into account the variability and virulence of the pathogen during interaction with the susceptible organism and the environment;

- calculation of the biological agent effect probability to the people with different immunity levels;

- possibility to preserve microorganisms in the source, within transfer factors of the infection pathogen;

- using statistical models of dependence between the dose, virulence and manifestation (type, severity) of health responses in a susceptible population, taking into account pathways.

This approach was practiced to validate the hygienic standard for the content of ractopamine in meat products. In accordance with the decision of the Codex Alimentarius Commission, the maximum permissible levels of ractopamine in pork and beef were set at $0.01 \mathrm{mg} / \mathrm{kg}$, in liver: $0.04 \mathrm{mg} / \mathrm{kg}$, kidneys: $0.09 \mathrm{mg} / \mathrm{kg}$ [26].

At the same time, currently, ractopamine is banned for use in feed of farm animals in 80 countries of the world, including the European Union countries [27, 28], and authorized for use in pig breeding by 22 countries. Ractopamine is used in a number of countries as a feed additive, stimulating the build-up of muscle mass, reduction of fat mass and increasing the efficiency of using fodder for pigs, cattle, turkeys.

The Russian delegation position expressed at the $35^{\text {th }}$ session of the Codex Alimentarius Commission was that the permissible daily dose of ractopamine is insufficiently justified, and cannot be used to establish the 
maximum allowable levels of ractopamine in meat and by-products. The scientific basis for such position was the results of health risk assessment conducted by Rospotrebnadzor research organizations in collaboration with RAMS Research Institute of Nutrition.

Toxicological assessment of ractopamine in animal experiments did not allow for the unambiguous conclusions about the no observed levels. In experiments on mice, rats, dogs and monkeys, a number of dose-dependent effects were recorded at orally administered intakes of 2 to $568 \mu \mathrm{g} / \mathrm{kg}$ of body weight, including an increasing heart rate and heart left ventricle contractions amplitude, a decrease in both systolic and diastolic blood pressure. Several studies revealed that effects (e.g., bradycardia in dogs) were also observed with minimal exposure [27, 29].

In assessment of health risk associated with the receipt of ractopamine residual amounts with food recommended by the Codex Alimentarius Commission conducted in Russian Federation, the information on uterine leiomyoma development in an experiment was used as the initial data for the formation of exposure-effect model for calculating the carcinogenic risk level in mice [30]. It was determined that the carcinogenic risk would correspond to an acceptable level.

For non-carcinogenic effects, simulation of the exposure-effect dependence was carried out on based on the data provided by the European experts in the $\mathrm{FAO} / \mathrm{WHO}$ reports [31]. As a basic model, an evolutionary model of accumulating risk of cardiovascular system disorders was used, described in the methodological guidelines "Quantification of non-carcinogenic risk under exposure to chemicals based on the construction of evolutionary models. ${ }^{5}$.

In accordance with the mentioned document, a recurrence ratio of accumulating functional disorders risk for cardiovascular system is constructed in simulation by the formula 5 . In constructing a recurrence ratio of accumulating functional disorders risk for cardiovascular system under exposure to ractopamine from meat products, its toxicokinetics was taken into consideration (down-regulation in the body by $85 \%$ during the day [32]), and an increasing heart rate was considered as a marker effect.

This recurrence equation is the basis for constructing the evolution curve for the risk of cardiovascular system dysfunction under exposure to D-ractopamine dose (the calculated risk) and its associated curve without taking into account the effect of ractopamine $(\mathrm{D}=0)$ (the background risk).

An assessment of non-carcinogenic risk to health coming from food was made for two scenarios: the content of ractopamine in amounts recommended by the Codex Alimentarius Commission as an MRL and at the limit level for ractopamine quantitative determination in meat products.

As a result of modeling cardiovascular system dysfunctions, it was found that when implementing the first scenario (intake of foods containing ractopamine at the level of residues proposed by the Codex Alimentarius Commission) the risk of cardiovascular system dysfunctions would be 0.47 , which, according to MP 2.1.10.0062-12 , is classified as an unacceptable risk. In assessing risk in the second scenario (intake of ractopamine with food at the limit level for quantitative determination), the risk of cardiovascular system dysfunctions would be 0.141 , which, according to MP 2.1.10.0062-12, is also classified as unacceptable. This level of risk can also lead to a reduction in the life expectancy due to additional cases of cardiovascular system disorders (diseases characterized by high blood pressure, atherosclerotic heart disease).

As aforesaid, ADI value, adopted as the basis for establishing MRL for ractopamine ranges within $0-1 \mu \mathrm{g} / \mathrm{kg}$ of body weight, i.e. not authentically different from zero, and therefore cannot be used in practice, in particular, when determining the permissible residues of ractopamine in meat products.

The presented experience of health risk assessment in validating hygienic criteria for food safety in the EAEU and Russia can be

\footnotetext{
${ }^{5} \mathrm{MG}$ 2.1.10.0062-12. Qualification of non-carcinogenic risk under exposure to chemicals based on the construction of evolutionary models: Methodical guidelines. - M.: Rospotrebnadzor's Center for Hygiene and Epidemiology, 2012 - 36 c.
} 
useful for improvement and international harmonization of risk assessment. As the basic directions in this process, it is advisable to consider:

- convergence of scientific approaches to the assessment of risk to consumers health when validating the hygiene standards;

- harmonization of risk assessment tools;
- exchanging experience and constructive international discussion on the practice for validating the hygienic standards.

Funding. The research was not granted any sponsor support.

Conflict of interests. The authors state there is no any conflict of interests.

\section{References}

1. CAC/GL 62-2007 Working Principles for Risk Analysis for Food Safety for Application by Governments. Rome, 2007, 41 p.

2. Evaluation of certain veterinary drug residues in food. Thirty-sixth report of the Joint FAO/WHO Expert Committee on Food Additives. World Health Organ Tech Rep Ser., 1990, vol. 799, pp. 1-68.

3. Evaluation of certain veterinary drug residues in food: fiftieth report of the Joint FAO/WHO Expert Committee on Food Additives. Geneva, World Health Organization, 1999, 108 p.

4. Toxicological evaluation of certain veterinary drug residues in food. WHO Food Additives Series, 1996, № 38, nos 873-883 on INCHEM. Available at: http://www.who.int/foodsafety/publications/monographs/en/ (16.04.2017).

5. Zaitseva N.V., Shur P.Z., Aminov A.I., Kiryanov D.A., Kamaltdinov M.R. To estimate the additional risk of diseases of the gastrointestinal tract associated with dysbiosis of the intestinal microflora due to the impact of tetracycline residues in foods. Zdorov'e naseleniya i sreda obitaniya, 2012, no. 7, pp. 46-48 (in Russian).

6. Moubareck C., Gavini F., Vaugien L., Butel M.J., Doucet-Populaire F. Antimicrobial susceptibility of bifidobacteria. J Antimicrob Chemother, 2005, vol. 55, no. 1, pp. 38-44.

7. Foodborne listeriosis. Report of the WHO Working Group. Bulletin of the World Health Organization, 1988, vol. 66, no. 4, pp. 421-428.

8. Mead P.S., Slutsker L., Dietz V., McCraig L.F., Bresee S., Shapiro C., Griffin P.M., Tauxe R.V. Foodrelated illness and death in the United States. Emerging Infectious Diseases, 1999, vol. 5, no. 5, pp. 607-625.

9. CDC [U.S. Centers for Disease Control and Prevention]. 1998. 1997 Annual Report. CDC/USDA/FDA Foodborne Diseases Active Surveillance Network. CDC's Emerging Infections Program (Revised 14 March 2000). Available at: https://www.google.com/url?sa=t\&rct=j\&q=\&esrc= s\&source $=$ web\&cd $=1 \&$ cad $=$ rja\&uact $=8 \&$ ved $=2$ ahUKEwiYjJLAus7eAhWJDSwKHadkCMEQFjAAegQ ICRAC\&url=https \% 3A \% 2F \% 2Fwww2a.cdc.gov \% 2Fncid \% 2Ffoodnet \% 2Fsteering \% 2F $2004 \%$ 2Fjune \% 2FJune04 packet.pdf\&usg=AOvVaw0UNrRvIsjf23RQ3IeZZOUB (23.03.2017).

10. FDA/FSIS [U.S. Food and Drug Administration/Food Safety and Inspection Agency (USDA). 2001. Draft Assessment of the relative risk to public health from foodborne Listeria monocytogenes among selected categories of ready-to-eat foods. Center for Food Safety and Applied Nutrition (FDA) and Food Safety Inspection Service (USDA). Available at: https://www.foodsafety.gov/ dms/lmrisk.html (24.06.2013).

11. Guidelines On The Application Of General Principles Of Food Hygiene To The Control Of Listeria Monocytogenes In Foods. CAC/GL61-2007, 2007, 28 p. Available at: http://www.fao.org/input/download/standards/10740/CXG_061e.pdf(16.04.2017).

12. Principles and guidelines for the establishment and application of microbiological criteria related to foods. Codex Alimentarius Volume 1B General requirements (Food hygiene), 1997, 4 p.

13. Commission regulation (EC) No1441/2007 of 5 December 2007 amending Regulation (EC) No2073/2005 on microbiological criteria for foodstuffs. EUR-Lex. Available at: https:/eur-lex.europa.eu/eli/reg/2007/1441/oj (16.04.2017).

14. Haas C.N. Estimation of risk due to low doses of microorganisms: a comparison of alternative methodologies. American journal of epidemiology, 1983, vol. 118, pp. 573-582.

15. Rose J.B., Haas C.N., Regli S. Risk assessment and control of waterborne giardiasis. American journal of public health, 1991, vol. 81, pp. 709-713.

16. Risk assessment of Listeria monocytogenes in ready-to-eat foods: interpretative summary (Microbiological risk assessment series; no. 4). Geneva, World Health Organization, 2004, 81 p. 
17. Lindqvist R., Westöö A. Quantitative risk assessment for Listeria monocytogenes in smoked or gravad salmon/rainbow trout in Sweden. International Journal of Food Microbiology, 2000, vol. 58, pp. 181-196.

18. Rekomenduemye nabory produktov dlya pitaniya beremennykh zhenshchin, kormyashchikh materei i detei do 3-kh let (Razrabotany GU NII pitaniya PAMH) [Food products recommended for consumption by pregnant women, breast-feeding mothers, and children under 3 (Drawn up by Scientific Research Institute for Nutrition of the Russian Academy of Sciences)]. Registr. Available at: http://www.rlsnet.ru/articles_467.htm (16.04.2017) (in Russian).

19. Shur P.Z., Kiryanov D.A., Atiskova N.G., Chigvintsev V.M., Khrushcheva E.V. Justificaion of acceptable nitrate levels in crop product using health risk criteria. Zdorov'e naseleniya $i$ sreda obitaniya, 2013, vol. 248, no. 11, pp. 47-48 (in Russian).

20. Shuval H.I., Gruener N. Epidemiological and toxicological aspects of nitrates and nitrites in the environment. Am. J. Public Health, 1972, vol. 62, no. 8, pp. 1045-1052.

21. Ingested Nitrate and Nitrite and Cyanobacterial Peptide Toxins. International Agency for Research on Cancer (IARC), Monographs on the Evaluation of Carcinogenic Risks to Humans. Geneva, World Health Organization, 2010, vol. 94, 464 p.

22. Metodologiya otsenki riskov zdorov'yu naseleniya pri vozdeistvii khimicheskikh, fizicheskikh i biologicheskikh faktorov dlya opredeleniya pokazatelei bezopasnosti produktsii (tovarov) / Evraziiskaya ekonomicheskaya komissiya [Health risk assessment methodology under exposure to chemical, physical, and biological factors for determining criteria of products (goods) safety / The Eurasian Economic Commission]. Moscow, Yumanite Media, 2014, 115 p. (in Russian).

23. Kamaltdinov M.R., Kiryanov D.A. The application of recurrent relations for integrated health risk assessment. Zdorov'e sem'i - 21 vek, 2011, no. 3. Available at: http://www.fh-21.perm.ru/download/2011-3-6.pdf (16.04.2017) (in Russian).

24. Zaitseva N.V., Shur P.Z., May I.V., Kiryanov D.A. Approaches to the assessment of integrated health risk population based on evolution of mathematical models. Zdorov'e naseleniya i sreda obitaniya, 2011, no. 10, pp. 6-9 (in Russian).

25. Zaitseva N.V., Shur P.Z., Kiryanov D.A., Kamaltdinov M.R., Tsinker M.Yu. MEthodical approaches for health population risk estimation based evolution models. Zdorov'e naseleniya i sreda obitaniya, 2013, vol. 238, no. 1, pp. 4-6 (in Russian).

26. Residue evaluation of certain veterinary drugs. Joint FAO/WHO Expert Committee on Food Additives. Meeting 2010 - Evaluation of data on ractopamine residues in pig tissues. Available at: http://www.fao.org/docrep/012/i1618e/i1618e00.pdf(16.04.2017).

27. Scientific Opinion of the Panel on Additives and Products or Substances used in Animal Feed (FEEDAP) on a request from the European Commission on the safety evaluation of ractopamine. The EFSA Journal, 2009, vol. 1041, pp. 1-52.

28. Alemanno A., Capodieci G. Testing the Limits of Global Food Governance: The Case of Ractopamine. European Journal of Risk Regulation, 2012, vol. 3, 12 p.

29. Evaluation of certain veterinary drug residues in food. Sixty-second report of the Joint FAO/WHO Expert Committee on Food Additives. WHO technical report series 925. Rome, 2004. Available at: http://apps.who.int/iris/bitstream/handle/10665/43039/WHO_TRS_925.pdf?sequence=1 (16.04.2017).

30. Williams G.D. A Chronic Toxicity Study of Ractopamine Hydrochloride Administered Orally to Beagle Dogs for One Year. Unpublished report on study No. D05885 from Toxicology Division, Lilly Research Laboratories, Division of Eli Lilly and Company, Greenfield, IN, USA. Submitted to WHO by Elanco Animal Health, Division of Eli Lilly and Company, Indianapolis, IN, USA. June, 1987, 66 p.

31. WHO. Food additives series: 53 ractopamine (addendum) First draft prepared by Professor Fritz R. Ungemach. IPCS INCHEM. Available at: http://www.inchem.org/documents/jecfa/jecmono/v53je08.htm (16.04.2017).

32. Residues of Some Veterinary Drugs in Animals and Foods. FAO. Rome, 1993, 179 p.

Shur P.Z., Zaitseva N.V. Health risk assessment when giving grounds for hygienic criteria of food products safety. Health Risk Analysis, 2018, no. 4, pp. 43-56. DOI: 10.21668/health.risk/2018.4.05.eng

Received: 22.10 .2018

Accepted: 15.11 .2018

Published: 30.12.2018 